\title{
Finding "Space" for Comanagement of Forests within the Neoliberal Paradigm: Rights, Strategies, and Tools for Asserting a Local Agenda
}

\author{
Evelyn Pinkerton • Robyn Heaslip • Jennifer J. Silver • \\ Kira Furman
}

(C) Springer Science + Business Media, LLC 2008

\begin{abstract}
As neoliberalism continues to influence environmental governance, it affects notions about the appropriate level of community involvement in resource management. Under more recent iterations, hybrid forms of governance are emphasized, including government-civil society partnerships and approaches geared towards harnessing the strengths of local communities. Here we explore the characteristics of different resource management rights, strategies, and tools through which communities can find political space to assert their own agendas within a neoliberalized policy environment. We examine the successful use of some of these approaches by communities during the initial development of community forests policy and practice in British Columbia, Canada. While we confirm the complex, contingent and case-specific nature of opportunities for comanagement created through neoliberal policy elements, we suggest that space does exist for community forest bodies to assert local values, goals and strategies, demonstrating the creativity, ingenuity and determination of communities to attain a real voice in management.
\end{abstract}

Keywords Comanagement · Neoliberalism .

Community forests $\cdot$ Counter-mapping $\cdot$ British Columbia

\section{Introduction}

In an earlier paper (Silver et al. 2007), we considered how neoliberalism and comanagement differ in ideology and

E. Pinkerton $(\varangle) \cdot$ R. Heaslip $\cdot$ J. J. Silver $\cdot$ K. Furman

School of Resource and Environmental Management,

Simon Fraser University,

Burnaby, BC, Canada, V5A 1S6

e-mail: epinkert@sfu.ca preferred tools for governance yet, in more recent iterations of neoliberalism, share a theoretical middle ground based on their common conceptualization of citizen power. We identified ten political "spaces" where this convergence appears: a focus on decentralization, the desire for government-local partnership, the potential for community-driven problem solving, a recognition of grassroots power in improving the public good, the desire to partially delegate management rights to communities, the practice of cultivating local initiatives via non-governmental bodies, the recognition that individual empowerment drives civil society, the (economic) valuation of local knowledge and expertise, the recognition that localized norms gain political legitimacy (albeit via the market), and the need for formalized citizen participation on management boards. We are more optimistic than some scholars who believe that comanagement initiatives will be merely co-opted by the neoliberal agenda, and that there is little or no "political space" (St. Martin 2001; Swyngedouw 2005) for their authentic development under a neoliberal regime. Other scholars emphasize the complex, contingent, and casespecific nature of the opportunity (Lemos and Agrawal 2006; McCarthy 2006).

Recent analyses have distinguished "roll-out" from "rollback" neoliberalism, in an attempt to conceptualize different phases in the neoliberal project and the types of governing approaches used in each. Roll-back neoliberalism refers to the restructuring of state-based regulation in ways that promote privatization, free trade, deregulation and global competitiveness (Lockie and Higgins 2007). This is sometimes characterized as a withdrawal (or "rollback") of state intervention in favor of "market rule". The more recent "roll-out" variants of neoliberalism are comparatively creative and draw together technocratic economic management with a deeply interventionist agenda in social and environmental issues (Lockie and Higgins 2007). 
Roll-out neoliberalism seeks to more actively create conditions for the rational and effective operation of markets as a response (or form of crisis management) to the problems associated with the roll-back variants (Peck and Tickell 2002; Lockie and Higgins 2007; Lemos and Agrawal 2006).

While the emerging literature on roll-out versus roll-back neoliberalism normally refers to twenty-first century changes in political approaches and ideologies, we use these terms more broadly to categorize political actions surrounding community forests of both past and present British Columbia (BC) governments. The advantage of this approach is that "it allows an engagement and debates over whether and how we can identify and analyze 'neoliberal' elements amidst the complex, heterogeneous specificities of empirical cases" (McCarthy 2006). While the categories of roll-out and roll-back neoliberalism have only recently been developed, we have found that the elements they represent were present at different points in $\mathrm{BC}$ political history in hybrid form, and categorizing them as such is a useful exercise.

The BC Community Forests program emerged from the governance dilemma of contending constituencies, which led to the introduction of some important elements of governance broadly thought of as aspects of roll-out neoliberalism, and as such provides a useful test of the hypothesis that, in some cases, roll-out neoliberalism may afford the political space for the assertion of rights and the use of strategies and tools which permit the authentic emergence of comanagement. Following the nuanced analysis of McCarthy (2006) that this an open question, we look more closely at the rights, strategies, and tools asserted and used by $\mathrm{BC}$ community forests. In the process of doing this, we also find ourselves examining the claim by James Scott that the ideologies of dominant groups create conditions, categories, and claims under which these same ideologies can be successfully challenged (Scott 1985), a question which overlaps with our first question, and which has preoccupied anthropologists and human geographers alike.

\section{Methods}

Our analysis emerges from discussions beginning fall 2006 within the comanagement research group in our graduate program, whose most active continuing members in summer 2007 comprise the coauthors. We reviewed and discussed literature on neoliberalism and various forms of comanagement, including community forests. The first author also conducted a year of preliminary research on BC community forests involving literature review, government document review, attendance of the annual conference of the BC Community Forests Association (BCCFA) ${ }^{1}$, interviews, emails, and informal telephone conversations with staff of the BCCFA, the BC Ministry of Forests and Range (MOFR), staff or board members of five BC community forests, and foresters knowledgeable about the history of $\mathrm{BC}$ forest policy development and practice. A number of these individuals reviewed earlier drafts of this paper.

\section{Historical and Political Context of Community Forestry in British Columbia}

We illustrate how a comanagement initiative has successfully used the political space created by neoliberalism by first briefly considering the political conditions which produced the $\mathrm{BC}$ Community Forests Program. Previous analyses of the BC Community Forests Program show skepticism that existing power structures leave more than temporary and fluctuating space for local initiatives (McCarthy 2006). However, an examination of a broader political context and recent development allows more optimism. The two decades preceding creation of the Community Forests Program reveal its emergence from a social movement demanding more sustainable forest practices, of which the movement supporting community-based management was a part (Pinkerton 1993; Burda et al. 1997; Cashore et al. 2001; M'Gonigle 1998a, b). The growing strength of the environmental movement, and its expression in logging blockades, reflected increased public awareness of the loss of old growth forests and an accompanying demand for more protected areas and higher environmental standards in logging. The $\mathrm{BC}$ government began responding even before the New Democratic Party (NDP) was elected in 1991, an election it won partly because of the popularity of its "greener" platform. The province then began taking tangible, incremental steps in response to this public pressure, including: The Forest Resources Commission (Peel 1991), The Old Growth Strategy (MOF 1992), The Protected Area Strategy (Province of BC 1993), and planning processes at various scales from large regional (Commission on Resources and Environment 1992) to small regional (LRMP 1992) to Landscape Unit (Klenner and Huggard 1995), which became reflected in the Forest Practices Code Act (1994). The latter built upon the preceding initiatives to lay out standards and procedures for the protection of environmental values in forest management.

\footnotetext{
${ }^{1}$ The BCCFA is a network of rural, community-based organizations in $\mathrm{BC}$ that are engaged in community forest management, as well as those seeking to establish community forests. It sees itself as part of a global movement committed to culturally, ecologically, and economically sustainable forestry. See Gunter (2004) for a discussion of the vision.
} 
But the newly-elected NDP also drew major support from the labor movement, only portions of which were green in the 1980s and 1990s. The leadership of the International Woodworkers of America, the union representing the majority of loggers and millworkers, had chosen to ally itself with the major corporate holders of logging rights (Hayter 2003; Prudham 2007). The NDP attempted to reconcile its contending constituencies through promises that the protection of environmental values would not be at the expense of jobs. Ironically, it was environmentalists who declared at this point that "the government is irrelevant; it is the marketplace [that will decide]", and persuaded the retail giant Home Depot to boycott wood products from forests labeled endangered by environmentalists (Wilson 2001). The NDP was eventually able to broker a Jobs and Timber Accord among the warring constituents. One notable area of agreement by environmentalists, unions, and major timber corporations in this Accord concerned the creation of community forests. For unions and corporations, community forests were a better alternative than more parks, consumer boycotts, and blockades. For BC environmentalists community forests promised an alternative greener than that practiced by the majors $^{2}$ (Burda et al. 1997; Hoberg 2001; McCarthy 2006).

Thus the political space for community forests was originally created by important elements of a roll-out neoliberal approach to resolving the dilemma of contending constituencies. This involved a recognition of the capacity of the environmental movement to use market instruments, and the potential for community-driven problem solving between environmentalists and forest workers, a theoretical space hypothesized by Silver et al. (2007) and realized in certain regions and periods in BC history (Pinkerton 1993; Prudham 2007). The nature of the rights and tools available in this space resulted from incremental policy development toward greater environmental protection and community involvement in the 1990s. However, in the following decade when the NDP left office, analysts were generally skeptical to pessimistic about the ability of community forests to retain that political space and to achieve actual comanagement (Hayter 2003; McCarthy 2006). Our goal is to examine to what extent this pessimism is warranted, and to what extent community forests have been able to retain and apply the rights, strategies, and tools created both through and in the face of roll-out neoliberal policy developments in the 1990s. We also consider to what extent additional political space has been created under new

\footnotetext{
${ }^{2}$ We use "majors" as the common shorthand for the large multinational corporations with integrated timber harvesting and milling capacity in more than one country. In BC these corporations had been granted long-term leases involving rights to harvest Crown timber but some $95 \%$ of timber was still owned by the Crown.
}

iterations of neoliberalism (sometime roll-back) in the twenty-first century.

\section{British Columbia's Community Forests Program: 1998-2007}

The Community Forests Program of the British Columbia Ministry of Forests and Range (MOFR) was launched through amendments to the B.C. Forest Act in 1998, providing the statutory framework for the Community Forests Pilot Program. Between 2000 and 2004, 11 pilot Community Forest Agreements (CFAs) were awarded for five-year terms, to be renewable after a provincial assessment. By June 2007, five of the original community forests had been assessed and issued 25 year tenures, signaling the confidence of the MOFR in their success, while three early pilots encountering difficulties were renewed for a probationary five years. Ten more recent applicants held five-year probationary agreements bringing the total to 18 community forests altogether. In 2005 community forests held about $0.1 \%$ of timber supply and major corporations $74 \%$. In 2003, the MOFR announced that its Forestry Revitalization Plan would reallocate $20 \%$ of the annual allowable cut away from the major corporations, awarding half of this to First Nations, community forests, and woodlots, and the other half to log markets and auctions, with the goal of allowing the free market to become more influential in determining log prices. By 2007, when some of these reallocations began to come into effect, the Community Forests Program accounted for about $1.5 \%$ of the total annual allowable cut. ${ }^{3}$

Government and community objectives for the Community Forests Program emphasized three main concerns: (1) providing long-term opportunities for achieving a range of community objectives, including employment and other social, cultural, and environmental benefits, (2) the creation of value-added industries, (3) environmental stewardship. Thus in theory there was encouragement and opportunity for communities to create a vision and set of objectives which differed from that of major industry and even government, an objective of roll-out neoliberalism. But we shall see below that this aspiration involved considerable challenges in practice, given the more limited set of rights given to community forests. In pursuing our main question about whether neoliberal governance allows political space for comanagement, we now turn to the question of what tools and strategies community forests use to overcome these challenges and occupy political space. If

\footnotetext{
${ }^{3}$ It appears that the MOFR is reserving judgment about how much the program might further expand, since the tenure taken back from the majors has not been fully reallocated.
} 
the five community forests receiving 25 year tenures are considered neoliberal "success stories" (if success is defined as meeting the expectations and requirements of the program administrators), to what extent are they also comanagement success stories?

We address these questions by focusing first on the weaker rights allocated to community forests, and on the strategies used particularly by the Harrop-Procter Community Forest, one of the five "successful" pilots awarded 25 year tenures, because it is the best documented so far and because it is the community forest that has put the most effort into asserting its own values and priorities where these differ from those of the state. We begin by examining how much political space was available to the HarropProcter Community Forest in several ways. First we ask at a general level (1) how the bundle of rights held by the community forest defines the roles of the state, the community, and the market in ways that constrain or permit the community to achieve its goals. Then we examine (2) the mechanisms used to keep the community accountable to its goals both in the eyes of the community and in the eyes of the state (i.e., how well the rights were implemented in practice). Finally, we examine (3) to what extent the welldocumented tool of "counter-mapping" has enabled the community to exercise its rights and assert its vision in the face of the neoliberal ideal.

\section{Rights Allocated to Community Forests Create Political Space}

When the Community Forests Program was created in BC, no extensive effort was put into designing a separate tenure arrangement or system of rights to reflect a vision or set of goals and objectives differing from those of the majors. Instead, community forests were granted a form of tenure called a Community Forestry Agreement (CFA) whose rights largely mimic the extensive rights of the major timber companies, but are simply more limited in scope. This suggests that the tacit goal of the state was to make communities junior partners in the established management system with a smaller subset of the same rights as the major timber companies, not to allow the creation of a different set of rights, goals, and objectives. In other words, community forests were designed to fit into the neoliberal system, rather than act as an alternative to it. Rights of community forests under CFAs include: (a) creation of an inventory of timber supply, and conducting timber supply analysis, (b) access to lands within the boundary of the community forest and withdrawal of timber from that land, (c) regulation of logging activity through five-year management plans, (d) enhancement of timber production through silvicultural techniques (replanting, thinning, etc.), (e) exclusion of outsiders from timber in the CFA area, (f) allocation of opportunities to $\log$ the CFA area to insiders, and $(\mathrm{g})$ enforcement of its plan.

These rights are limited by the right of the state (MOFR) to set standards for, review, and comment on the management plan and the rate of logging (annual allowable cut) every five years. As such it is a fairly "complete" (Pinkerton 2003) form of comanagement in which the community enjoys a high level of initiative in making the management plan (e.g. where, what, when, and how to $\log$ ) and could be said to hold the balance of power once the tenure has been awarded. However, a CFA does not include the (h) rights of alienation (selling or leasing) held by the majors, and community forests hold only a weak version of the majors' de facto (i) right to influence policy and de facto (j) right to return optimum value to producers, as discussed below. The preceding list of rights is taken partially from Schlager and Ostrom (1993) [b,c,d,e,f,g,h] and partially from Pinkerton and Weinstein (1995) [a,b,c,d, e,f,g,h,i,j].

Despite these extensive rights surrounding logging, the right of community forests $(j)$ to return optimum value to producers is weak because of the small land and timber base awarded, the small amount of operable timber (that which can be actually harvested because of where it is located) available on this base, the more difficult terrain usually available for community forests, and (usually) the lack of a mill. Thus community forests must compensate for the lack of economies of scale ${ }^{4}$, the more difficult logistical problems, and thus the higher operating costs by other means. Unlike the majors, only a few community forests have their own mills, and any local independent mills that may exist do not necessarily offer competitive prices for timber. Community forests thus face a dilemma of whether to support local community businesses at a noncompetitive price, or face higher transportation costs to get more competitive prices (Cathro 2004).

To our knowledge, only two community forests, Revelstoke (a community owned Tree Farm License created earlier in 1993, although a member of the BCCFA), and Creston (a temporary tenure holder which is applying for a CFA) have regularly scheduled log auctions in which they obtain competitive prices for their timber. These log auctions were based on a 1993 government model

\footnotetext{
${ }^{4}$ The BCCFA estimated after an extensive discussion at their 2005 AGM that a minimum annual allowable cut of $50,000 \mathrm{~m}^{3}$ in the interior and $25,000 \mathrm{~m}^{3}$ on the coast is necessary for a viable community forest, because of the costs of infrastructure (approximately $\$ 200,000 /$ year). Only six of BC community forests operating in 2007 meet this criterion for viability. Not all community forests agree with this estimation applies universally, because of differing situations regarding NTFPs, possession of a mill, and access to competitive local markets.
} 
exemplifying the roll-out neoliberal idea of giving communities access to markets. The local log market in the Vernon District of the Kamloops Forest Region became the government-operated pilot to respond to the recommendation of the government's 1991 Forest Resources Commission to test the economic and technical viability of alternative logging practices, combined with selling such $\operatorname{logs}$ in a MOFR public auction that would allow small wood product manufacturers in the region access to wood and increase financial returns on timber harvested under alternative logging practices. The forester in charge of the Small Business Enterprise Forest Program of the MOFR in the Kamloops Region laid out the logging plans for $5 \%$ of his annual allowable cut which incorporated higher environmental standards, cultivated and hired contract loggers to cut and transport the timber to the Vernon log sort yard. By sorting logs into 48 different grades and selling "character" and lower-value wood which would have been discarded by the major mills, the MOFR demonstrated that a log sort yard "is a very big part of the solution to both environmental concerns and log supply for small operators" (Smith 1997; Mater and Mater 1998). Many small businesses which added value to wood through manufacturing could not operate without a guaranteed wood supply.

The log sort yard operated successfully for nine years 1993-2002 and, according to the forester in charge, demonstrated that a small competitive log market generates about four times the gross revenue of current industrygovernment tenure models. Others emphasize that net revenue was c. $\$ 45$ per cubic meter vs. $\$ 15$ per cubic meter through the tenure system. In spite of the increased costs to government of administering the logging and auction activities, the log sort yard returned one-and-a-half times the cost of its operation to the Ministry in the form of increased revenues from the sale of logs (Smith 1997; Donovan 1999). Alternative environmentally sensitive logging costs were higher, but these were more than offset by greater utilization of wood, higher value obtained for wood, and higher government revenues (Mater and Mater 1998).

Given their higher logging costs and desire to protect social and environmental values, it is clear that community forests require access to such a log sort yard and public auction to more effectively recover the potential value of their wood. Most community forests have so far not solved the organizational and logistical problems of volumes too small to support individual log yards. ${ }^{5}$ However, through the creation of the Vernon Log Market, this aspect of the roll-out version of neoliberalism was able to create political space in the form of a model for community forests to gain

\footnotetext{
$\overline{5}$ According to interviewees, one economic analysis with widespread credibility estimates that a $\log$ yard sort requires at least $45,000 \mathrm{~m}^{3} /$ year to be reasonably profitable.
}

meaningful access to markets, at least one community forest has been able to permanently incorporate this model into its ongoing operations and to retain the political space to the present day. The log sort yard and auction model is an economic one in illustrating the economic viability of alternative logging methods, of utilizing a greater spectrum of wood and of getting better prices for wood, as well as returning higher royalties to government. The model is also political in that it showed that community forests needed independent access to the market (vs. selling only to the majors' mills) to demonstrate that much wood discarded by the majors has economic value and that even higher value wood can be sold at still higher prices to value-adding small industries such as furniture manufacturers. Large industries with mass production strategies tend to prefer to control supply of raw product as a way of controlling price, and to be less interested in small local production of many diverse products which involves multiple skills and high transaction costs (Pinkerton 1987). Aside from experimentation with flexible production and niche marketing when the political and economic conditions favoured it ca. 19872000 (Hayter 2003; Young and Matthews 2007), this strategy continues to be the one most pursued by the majors and has been enabled by $\mathrm{BC}$ forestry policy.

Community forests' access to markets was challenged in a new way when the NDP left office in 2001. A Special Advisor to the Forests Minister (Pearse 2001) was created when the provincial Liberals returned to power, who recommended removal of impediments to the free flow of goods, in order to establish competitive log prices. This roll-back neoliberal action removed encumbrances on tenure holders which freed major forest companies from 50 -year-old policies that had tied access to timber to social objectives such as retaining jobs and value-added production in $\mathrm{BC}$ communities. Policies adopted from this vision and consequent 2003 and 2004 legislation (Forest Revitalization Act, Forest Revitalization Amendment Act, and Forest Statutes Amendment Act) resulted in the closure of the Vernon Log Yard Sort (in 2002), the abolition of the appurtenancy clause which required some log processing by local mills, and any restrictions on sale of mills or tenures by the Minister (Marchak and Allen 2003) and weakened log export restrictions. In theory and according to the MOFR, the majors now control c. $54 \%$ of production. According to Marchak and Allen (2003), the aim of the legislation was for majors to retain c. $60 \%$ of the annual allowable cut in long-term tenures. Economists Niquidet and van Kooten (2006) note that this level of concentration could still confer oligopsonistic power upon the majors. In practice, it appears that the Forest Revitalization Plan has acted to consolidate and further concentrate the allowable annual cut by the majors, so there are now only four key players in BC (Hamilton 2006; Dobbin 2006), with larger 
firms now controlling 93\% of renewable tenures (Maness and Nelson 2007). So it is not surprising that some analysts imagine a scenario in which both small business and community forests risk corporate buy-outs or bail-outs of mills (Krogman and Beckley 2002). A roll-back neoliberal policy with the stated goal of removing impediments to the free play of the market has resulted simultaneously in the removal of domestic and international barriers to market transactions and also in the creation of much clearer oligopsonies which curtail free market competition.

However, the impact of these recent policy changes, containing elements of a roll-back neoliberal approach are complex and not uniformly negative. One previouslymentioned element of this change was the reallocation of $20 \%$ of the cut away from the majors (some of which went to community forests) because of US pressure to remove impediments to "market rule." As discussed in our earlier paper (Silver et al. 2007), more recent iterations of neoliberalism recognize the potential positive impacts of enabling communities to have greater access to markets, and this policy contained these roll-out neo-liberal elements alongside the roll-back "market rule" elements. In May 2007 the BC Community Forests Association exerted some degree of policy influence (i) when they persuaded the MOFR to continue the 2006 lower stumpage rates for community forests to reflect their distance from mills and their higher operating costs. This BC Liberal approach indicates an appreciation of the need to cultivate local initiatives, and the potential role that non-governmental organizations can play (Silver et al. 2007; Young and Matthews 2007), another roll-out element in the BC Liberals's neoliberal agenda. The MOFR also claims that they will consult with the BCCFA on the standards for judging future applicants for community forests, the process for the review of these applications, the terms of the pilot license, etc. At issue currently is whether the BCCFA will be able to maintain the original goals of the program that formerly required competitive applications and meaningful community engagement and management for a range of values besides timber. There is concern whether the current system of invitations to apply for community forests is already or will become a form of distributing political favors, opportunities to access timber and conduct business as usual. ${ }^{6}$ Thus the hybrid nature of the roll-out and even roll-back elements of neoliberalism in the twenty-first century continues to hold open some space for community forests.

One right potentially held by community forests which affects their ability to secure optimum value from forests is

\footnotetext{
${ }^{6}$ Recommendation \#19 in the 2006 Community Forests Program Review states that "A consistent proposal review, agreement award and issuance process should be applied throughout the province".
}

non-contentious but incomplete. Because logging operations alone do not return optimum value to most community forests, they may depend on other forest resources in addition to timber. In many cases, community forests can be expected to be financially viable to the extent that they can balance a number of economic uses of the forest. Nontimber forest products (NTFPs) are in theory a major avenue available to community forests to make their enterprise financially viable. Commercially valued NTFPs include berries, mushrooms, medicinal plants, decorative greens and recreation/tourism utilization. Although current CFAs can grant rights to manage and charge fees for the harvest of NTFPs, they include no right to exclude NTFP harvesters from physical entry into community forests. Thus community forests lack a firm legal basis for implementing their desire to manage and control mushroom harvests, for example. Therefore, only communities that are isolated and have poor road access are able to exercise de facto exclusion rights, and manage the NTFP harvests of a limited number of actors licensed by them. Harrop-Procter happens to have negotiated NTFP management rights explicitly in its CFA and, because of its relative geographic isolation, can exercise these rights.

However, the largest area of contention between the Harrop-Procter Community Forest (HPCF) and the MOFR involved a right and an area of governance not even mentioned yet: the right to manage for ecosystem values and services (in this case clean domestic water being primary). We conceptualize this as (k), the right (or duty) to exercise stewardship. ${ }^{7}$ This right became contentious: the original intention of the 1994 BC Forest Practices Code to protect ecosystem values, or at least fish, wildlife, soils, water, etc., was curtailed by 1996 when a cabinet directive stipulated that the Code's provisions could not impact timber supply by more than $6 \%$. In other words, the declared intention of the act to mitigate harm to the environment from logging and road building would be exercised on a very small portion of the landscape. ${ }^{8}$ Consequently it is not surprising that in 2000, negotiations between the HPCF and the MOFR over terms of the tenure and the management plan involved a difference in opinion on what the annual allowable cut should be. MOFR wanted

\footnotetext{
${ }^{7}$ The range of benefits derived from community forests, including place-oriented identity, subjective well-being, economic and cultural stability, small-scale economic diversity, is not well discussed in the literature but should include the "obvious and sustained commitment of people to the places and ecosystems under their control" (Lerner 1993; Sheppard 2003).

${ }^{8}$ Environmental provisions limiting logging were further curtailed in subsequent years and governmental oversight of even these provisions severely limited by the inability of government in most cases to question the judgment of professionals privately contracted to approve logging plans (Marchak and Allen 2003).
} 
a range of possible cut volumes over the five year period to include a figure three times higher than the amount the HPCF eventually managed to negotiate into the final agreement (Pinnell and Elias 2002). HPCF based its annual allowable cut calculations on an analysis of its forest as a "landscape unit", applying provisions of the Forest Practices Code Act for how to conduct this analysis, as discussed below. HPCF's successful negotiation of a lower annual allowable cut demonstrates that the Code had indeed created some political space for comanagement, allowing the HPCF to far exceed the allowable $6 \%$ netdown because of their capacity to argue their case based on their own studies. ${ }^{9}$

In sum, while the $\mathrm{BC}$ Community Forests Program was created for complex reasons, key elements of the neoliberal paradigm regarding the benefits of partnering with communities were certainly involved. Furthermore the program has clearly been given some space to survive and grow in ways that suit local agendas. A well-prepared forest community with an analysis and plan drawing upon these policies was able to negotiate its vision by occupying available space, even on occasions when doing so was not the original intention of government policies. The main vulnerability of community forests is to market forces which advantage the dominant position of the majors, create high transaction costs for communities, challenge their ability to secure market value for raw logs, and at the same time force them to innovate to survive. In the next section we examine to what extent mechanisms by which community forests are held accountable to their goals help them occupy or expand political space for comanagement.

\section{Mechanisms of Accountability (Internal/External) as a Tool/Strategy to Take Advantage of Political Space}

The small communities (combined population 800) that form the HPCF are found $30 \mathrm{~km}$ northeast of Nelson, in southeastern BC. Over the 25 years (1975-2000) of trying to obtain control over their local forest, the values of these communities evolved and solidified (Elias 2000). Because this area of $\mathrm{BC}$ proposed the first community forest before there was a program (SVCFMP 1975) and has long been perceived by MOFR as a "hot spot" for activism (Pinkerton 1993), the agency seems to have applied particularly stringent standards of accountability. Logging rights were held by non-local companies, and logging activities had

\footnotetext{
${ }^{9}$ The funding, expertise, and studies done for HPCF to enable them to take this position are detailed in Elias (2000) and Pinnell and Elias (2002). The community performed additional studies to spell out its assumptions about protection needed for unstable slopes and the riparian zone, and the community and MOFR agreed to disagree on these assumptions.
}

been plagued for decades with blockades by citizens wishing to protect their domestic drinking water supplies in this unstable mountainous terrain. Citizens sometimes demanded that the logging companies post bonds which they would forfeit if their activities caused landslides. A locally-celebrated, internationally recognized, and controversial local resident forester, Herb Hammond, had been instrumental in organizing the $\mathrm{BC}$ Watershed Protection Alliance (BCWPA 1988) in support of such demands, and in promulgating standards for ecosystem-based forest management (Silva Forest Foundation 2004). The MOFR wanted to be certain that the proposed community forest genuinely represented community goals, values, and priorities, and not simply the views of an environmental minority.

Therefore, a major dilemma faced when the HPCF was finalized was creating a viable business strategy that met the goals of the MOFR, yet remained accountable to the community. Over time, the HPCF communities developed (a) an organizational form to represent community values and priorities in management, (b) vision, goals, and objectives for what the organization and community wanted their forest to be, (c) a method for the organization to make decisions and work with the community at each planning stage, (d) small value-added industries in both timber and NTFPs, (e) sufficient revenue, combined with volunteer labor, from these industries and from logging to support the operation of the community forest, (f) the tacit, if not active, support of First Nations whose traditional territories overlapped with the area of the HPCF. The last three strategies $(\mathrm{d}, \mathrm{e}, \mathrm{f})$ were mechanisms by which the HPCF was accountable to the goals of MOFR, in addition to their own goals. However, the MOFR was likely also under pressure from industry to consider the Harrop-Procter proposal with particularly critical eyes, as communities in the region were perceived as generally anti-logging and the proposed annual allowable cut was exceptionally low by industry standards.

Thus, the Harrop-Procter Community Forest can be seen as a stark illustration of a community with an ideology and goals at variance with those of the state. However, as is illustrated below, it used state imposed accountability mechanisms to its developmental advantage (i.e., occupied the political space they created). This political space includes the opportunity for developing processes for articulating localized norms and in turn, for these norms to gain political legitimacy. It also includes the cultivation of local initiatives where non-governmental organizations play a mediating role (Silver et al. 2007). This space may have opened due to an evolving roll-out neoliberal vision of decentralization in combination with stringent accountability (Silver et al. 2007). We discuss below the five accountability mechanisms built into the HPCF agreement 
and how they have been strategically used by the HPCF communities, as discussed in Elias (2000), Pinnell and Elias (2002), and the HPCF web page.

\section{(a) An organizational form which represented community values and priorities in management}

The Harrop-Procter Community and Watershed Protection Committee (HPCWPC) was first formed in 1984 when it was learned that a local logging plan has been made with no community input, despite efforts by the community to be involved in long-range planning since the mid-1970s. More intense dialogue with the MOFR followed and the community became involved in the Protected Area Strategy and Commission on Resources and Environment (CORE) discussions in the 1990s. Under the 1994 Forest Practices Code Act, when an area qualified as a landscape unit, the Ministry could develop a landscape-level plan to translate broad objectives into "clear and measurable targets and strategies to manage and conserve forest resources" and thus inform forest development (logging) plans. By 1996 it became obvious that these planning processes with the MOFR would not allow sufficient expression of community aspirations for their own area. Consequently, the HPCWPC held new elections and evolved into Harrop-Procter Watershed Protection Society (HPWPS) in order to take advantage of opportunities afforded by the 1994 legislation.

The HPWPS was able to use funding obtained by forester Herb Hammond to produce an ecosystem-based plan for the landscape unit comprised of the five watersheds in their area. Thereafter a newsletter was circulated along with a questionnaire to all residents presenting options for status quo, ecosystem-based management, or total preservation. Fifty percent opted for the ecosystem-based (landscape-level) management plan. Under the new legislation, such a plan required the establishment of a protected network of riparian zones, representative stands (e.g., old growth), sensitive areas (e.g., steep slopes), and crossvalley corridors before forest use zones could be established for any extractive activities. Even forest use zones (which ultimately made up $15 \%$ of the Harrop-Procter landscape planning unit) were required to apply stand-level standards to protect and maintain forest composition and function and prohibited clear-cutting as then practiced. Additionally, this process required participation by local communities in decision-making, equitable distribution of benefits to the local community, and maximizing employment of local workers.

Although various requests to government to support the landscape-level plan and some form of community-based management to accompany it failed for a few years, the HPWPS persevered, continuing to work on the plan and on communicating progress on it to the community. By the time they applied to become a pilot community forest under the 1998 amendments to the Forest Act, $60 \%$ of the community were members of the HPWPS. When the community forest pilot agreement was approved in principle, the MOFR conducted a public meeting, open house, and survey of $100 \%$ of community households to determine the degree of community knowledge and support, the facilitator's report noted "near-unanimous support".

For our purposes, what is most notable about this history is that two pieces of permitting legislation, the Forest Act and the Forest Practices Code Act created space for: (a) the organizational form that would be recognized as a legitimate representative of community interests (a communitybased society) and (b) the planning unit ("landscape unit") that could be managed by the community body at this scale and using these criteria (ecosystem-based management). The relevant sections of both acts could be considered to have roll-out neoliberal elements in that the first fostered a partnership with community-based groups and the second permitted community-driven problem solving, based on a recognition of grassroots power in improving the public good. The HPWPS was able to take advantage of this latter provision before it was removed in the later version of the Forest Practices Code (the FRPA) when the Liberal Party took over leadership of the province from the NDP in 2001. This demonstrated creativity at the local level in using a state-created mechanism to assert a local agenda.

\section{(b) Vision, goals, objectives for what the organization and community wanted their forest to be}

Throughout the near quarter-century preceding the creation of the HPCF, there was a core group of individuals both in the community and in the west Kootenay region who held a vision of local forests being locally managed in accordance with local values and with the majority of jobs being held by local people. As discussed above, this vision became articulated in greater and greater detail as the community found more opportunities to implement the vision with the aid of professionals, such as with the landscape-level plan. Interestingly, the high level of scrutiny by the MOFR over community support for the vision may have intensified the HPWPS's effort to educate and mobilize local public opinion. Thus accountability to government apparently increased accountability of the community to its members. Although the community forests program was created as part of a roll-out neoliberal agenda to delegate authority, increase competition, and place more accountability demands (social and environmental) on the community/civil society, in this case the state exercising oversight may have increased the assertion of a community agenda. Thus, the relationship more resembled that of comanagers rather than one of detached paternalism, and suggests that opportunities for collaboration and partnership in forest management may emerge just 
as, or more, successfully under a roll-out neoliberal paradigm than under a command and control approach. In other words, in a neoliberal regime, a community with a differing ideology is likely to encounter accountability demands, dictated by the state through their partnership. However, these demands may strengthen rather than weaken a community's commitment to its own vision, and its ability to implement it. Instead of the power struggles which characterize the development of a comanagement regime replacing command and control, this comanagement relationship may start with a more open (though still critical) state attitude. (The NDP government was willing to entertain innovation, but exercised considerable oversight and pressure for strict adherence to certain standards).

Through the landscape-level and forest development planning processes, the community also worked toward turning the vision of ecosystem-based management, community stability, and sustainability into other specific goals and objectives such as equity in the distribution of benefits, economic diversification and eco-certification. Economic diversification in the form of a specialty mill, and processing and marketing NTFPs has met both the neoliberal and community goals. Eco-certification, another neoliberal tool, has benefited the HPCF in gaining access to niche markets.

\section{(c) A method for the organization to make decisions and work with the community}

In the early stages of creating a vision, and affirming understanding of the vision, a variety of methods to engage the community were used by the HPWPS and its predecessor the HPCWPC, including surveys of opinion, newspaper articles, public meetings, workshops, radio programs, door-to-door information campaigns/petitions. As planning for ecosystem-based management became more specific, workshops were used to present and promote discussion on more detailed information. For example, Herb Hammond came to the community and made an extensive presentation on his analysis of landscape level values and processes. After government approval of the community forest, a Forest Planning Committee was formed and met with water users living adjacent to the area proposed for logging. Before submitting the 2000 required management plan to MOFR, the plan was presented at a community meeting. In 2001 a revised forest development plan was submitted to MOFR, but only after it was aired at a community meeting, including a open house with maps, plans, photographs of viewscapes, and a presentation by the specialists who had assessed the terrain and hydrology. Then a site plan for the specific area to be logged was prepared through meetings with a committee of five water-users representing those directly affected, including two field trips to view partial cutting scenarios, different logging systems, and to discuss both logging options and whether more assessments were needed. A two-day wildlife assessment was added, and the timing of logging altered to protect nesting birds. A terrain stability assessment was also added, but identified no risk. A monitoring procedure, using 45 permanent plots, was developed to measure changes in forest structure caused by logging. Finally, before logging occurred, 15 community members participated in marking trees to be cut, in order to appreciate the complexity of management considerations.

Likewise, the rules and principles for decision-making were collectively developed by the elected local board, representing all perspectives. Any community member could address a concern to either board, and participate in decisions, and the boards were required to provide a rationale for why a concern was not incorporated into a decision. This level of community participation in planning created very strong accountability to community goals, values, and members, clearly exceeding anything envisaged in permitting legislation and planning processes.

\section{(d) Small value-added industries in both timber and} NTFPS.

In 1999 the Harrop-Proctor Community Cooperative was formed as the primary business arm of the Society which made operational decisions, and took over as the signatory of the CFA from the HPWPS (although the latter held seats on the Cooperative board and did joint planning with them). The Cooperative was divided into two business branches: Sunshine Bay Botanicals, producing and selling tinctures, herbs, and teas of medicinal plants (some from the forest, some from adjacent agricultural land) and Harrop-Procter Forest Products, producing manufactured lumber (flooring, paneling, exterior decking, siding, timbers) and timber products (covered signboards, planter boxes, frame arbors, vegetable storage boxes). Both industries add significant value and are good examples of the connection between logging at a smaller scale for higher value wood and the production of higher value wood products.

(e) Sufficient revenue, combined with volunteer labor, from these industries and from logging to support the operation of the community forest.

The HPCF would not be able to operate at this scale without the up to 300 (now 200) hours a month of volunteer labor contributed by community members. Partly this is because the community has made significant investments in educating other community forests nationally and internationally. The HPCF example demonstrates that there is no simple rule for economic viability, but rather that a combination of strategies may be successful, including: (1) large mill ownership for better price or small specialized mill ownership to access niche valued-added markets (e.g., 
HPCF), (2) log yard sort auction for better price and higher utilization of wood not purchased by the majors or by the community's own mill (Revelstoke, Creston), (3) access to competitive local markets (Revelstoke, HPCF), (4) access to eco-labeled markets (HPCF), (5) NTFP production (HPCF), (6) volunteer labour (HPCF), and (7) operating at a scale of production which makes the management infrastructure supportable (see footnote 4). The HPCF must be seen as a unique case because it lacked both adequate scale and a $\log$ sort auction, but had volunteer labour, NTFPs, access to eco-labeled markets, and received so much attention and support as a pilot case that this compensated for these key missing factors.

(f) Tacit support of First Nations whose territories overlapped with the area of the HPCF.

The Ktunaxa-Kinbasket Tribal Council and the Sinix't Nation both consider the community forest to be situated within their traditional territories. The requisite letters for support for the creation of the community forest were supplied, and a protocol agreement with the Sinix't Nation was reached. All plans are sent to these First Nations for review. Various forms of engagement have taken place over the years, including meetings, fieldtrips, and a Ktunaxa camp-out in Harrop-Procter.

In sum, a number of mechanisms of accountability were used to address the HPCF's dilemma in having a viable business strategy that met the goals of the MOFR while remaining accountable to the values developed by the community which were considerably at variance with those of industry at large. While the MOFR used many mechanisms to assure that the goals of the HPCF were indeed supported by the majority of the community, the HPCF in turn was able to hold the MOFR accountable to the stated goals of the Landscape Unit planning process. The HPCF has been on the cutting edge of developing and marketing value-added products, especially non-timber forest products, a goal highly valued by the MOFR. The HPCF operates at a scale significantly smaller than what is generally deemed economically viable in BCCFA discussions $\left(2,600\right.$ vs. $\left.50,000 \mathrm{~m}^{3}\right)$. Therefore, HPCF's major challenges will continue to lie in the generation of sufficient revenue (offset by volunteer labor) from NTFPs and logging, to support ongoing operation.

\section{Counter-mapping as a Tool/Strategy to Take Advantage of Political Space}

Because the HPCF generated technical and cognitive maps in resistance to the agenda of the BC MOFR, a great deal of the work detailed above could be categorized as "countermapping", a tool for laying claim to specific uses of land in which the community has a cultural stake. As James Scott (1998) demonstrated, European state hegemony was established when the state imposed its own cadastral maps on a landscape previously illegible to it because of the complexity of communal rights, boundaries, and detailed uses of landscape. Through counter-mapping, local claimants use the state's language and tools to identify and reclaim their own uses of landscape (Brody 1981; Peluso 1995; Tobias 2000; St. Martin 2001).

It is useful to distinguish technical and cognitive dimensions of counter-mapping. Technical mapping enables concrete representation and communication of a landscape while cognitive maps express an alternative vision and permit the education and mobilization of public opinion. Both types of maps can express the local importance of various plants and animals by identifying their existence and their habitat needs, even if these have no direct utilitarian value to the general public. The generation of technical maps to lay out information in an organized way while identifying the existence of valued species (caribou, grizzly bear), opportunities (local recreation and tourism), and NTFPs is an effective communication tool between the community and state which can assist in the formulation of business and management plans. Both technical and cognitive counter-mapping occurred in the HPCF example described above.

In the HPCF example, counter-mapping was a way of reinterpreting the dominant neoliberal view of land, by naming and giving meaning to the resources valued by the community, some of which might be invisible on a more conventional map displaying resources only if they are considered to be marketable commodities. By using a language that was understandable to the state, the HPCF was also able to assert protection of areas and resources with multiple users and interests. In this case, the temporary identification of landscape-level planning in the Forest Practices Code provided an ideal bridge for the HPCF to assert its vision of ecosystem-based management and appropriate scale of management.

To our knowledge, there are very few occasions in which this planning tool has been successfully used on crown forest lands not previously set aside from development through a higher level planning process such as CORE or LRMPs. ${ }^{10}$ Feit (2004) and Langdon (2006) have examined how Cree hunters and Alaskan aboriginal fishermen communicate with both their own members and the state in a way which bridges these cognitive understandings of their territory and those of the state. They show how the ideologies of dominant groups create conditions, categories, and claims under which these rights, strategies and tools

\footnotetext{
${ }^{10}$ Hoberg (2001) notes that there were Landscape Units established in only three of BC's 40 Forest Districts.
} 
can be successfully used (Scott 1985). The Harrop-Procter Community Forest successfully used both the technical and the cognitive aspects of counter-mapping to assert their vision and to use state-legitimized planning processes to first assert and then to implement ecosystem-based management of their forest. As such, they demonstrated an important way in which a neoliberal state created conditions, categories, and claims under which a comanagement agenda could be asserted.

\section{Conclusions}

Our goal was to examine to what extent British Columbia community forests have been able to use and retain the political space created through policy developments in the 1990s and the following decade in order to create an authentic comanagement arrangement. By examining first the general historical and policy context, and then a specific case, we have found confirmation of the hypothesis that rollout neoliberalism affords political space for the assertion of rights and the use of strategies and tools to build comanagement. However, we also confirm the complex, contingent, and case-specific nature of this opportunity. For example, we found that a few community forests were in a position to learn from and apply the government-designed model of the $\log$ sort auction to obtain competitive prices for their timber, and to maintain this strategy even after this roll-out neoliberal policy was abolished in a return to roll-back neoliberalism after 2003. Likewise, we showed that an early version of legislation which identified a landscape planning unit and criteria for ecosystem-based planning was successfully used by a community forest even after the legislation had been revised to exclude these provisions. Thus some communities were able to seize opportunities to assert and retain the key rights to obtain optimum value for wood and to practice stewardship. We identified these as the weakest rights of community forests, and thus ones they were able to assert only through specific opportunities. These opportunities were consistent with specific elements in roll-out neoliberal policies which encouraged community access to markets and community-based problem-solving. Although we began with the assumption that only roll-out elements of neoliberalism would create space for comanagement, we discovered examples of even roll-back neoliberal policies intended to further market rule which favored the continuation and expansion of community forests, such as the reallocation of a portion of the cut away from the majors to small business and community forest programs and a reduction in the royalty (stumpage) fee paid by community forests.

To explore how a community forest used specific strategies and tools to assert these rights and to occupy the political space afforded by roll-out neoliberal policies, we chose the clearest example available of a community forest whose vision, goals, and ideology differed most dramatically from those of the state and the forest industry. We explored how the MOFR's requirement for stringent accountability was used by this community forest as an opportunity to articulate local values and norms, to thoroughly engage the community, and to mobilize community support. The strategies used by this community forest exemplify the claim that the ideologies of dominant groups create conditions, categories, and claims under which these ideologies can be successfully challenged (Scott 1985). Landscape unit planning as originally set out by government, was used as a tool for asserting the right to conduct ecosystem-based forest use planning. Countermapping was used to identify community values and opportunities to incorporate them into planning. The community forest and its board of directors developed an organizational form representative of the community, and strategies and tools for extensive communication work with the community at each planning stage, illustrating a highly developed form of accountability. This case illustrated an alternative strategy for economic viability, not through a log sort auction, but through non-timber forest products, small value-added secondary industries associated with timber and non-timber forest products and volunteerism.

Thus through the examples of three major strategies used by community forests (the assertion of rights to competitive markets, the assertion of rights to plan to accommodate their own values, and the use of NTFPs and small valueadded industries), we conclude that at least some community forests will be able to hold their own if they have either large enough scale and access to a log sort auction or sufficient alternative strategies such as value-added milling, NTFPs, access to eco-labeled markets, or volunteerism. It is possible that $\mathrm{BC}$ will succumb to pressure from the US and from the BC Liberal Party to privatize public forests, which would curtail the expansion of community forests unless these were classified as private. Barring detrimental policy and/or market developments, community forests with a sufficient number of these conditions will continue to occupy the political space created by neoliberal policies. As the mass production and low utilization strategies of major producers become less and less viable, and the public better understands the value of regional markets, higher utilization, and value-added industries, we expect that $\mathrm{BC}$ community forests will have their day.

Acknowledgements Thanks to Ramona Faust, Jim Smith, Thomas Maness, Ray Travers, John Welch, Jennifer Gunter, and Susan Mulkey for comments on earlier drafts. They are not, however, responsible for errors of fact or interpretation. Thanks to the Social Sciences and Humanities Research Council of Canada for supporting aspects of this research. 


\section{References}

British Columbia Ministry of Forests. (1992). An Old Growth Strategy for British Columbia, Victoria, BC, $74 \mathrm{p}$

British Columbia Watershed Protection Alliance. (1988). Handbook. Box 9. Winlaw, BC V0G 2J0.

Brody, H. (1981). Maps and Dreams. Douglas and McIntyre, Vancouver, BC.

Burda, C., Curran, D., Gale, F., and M'Gonigle, M. (1997). Forests in Trust: Reforming British Columbia's Forest Tenure System for Ecosystem and Community Health. Report series R97-2. Faculty of Law and Environmental Studies Programme, University of Victoria.

Cashore, B., Hoberg, G., Howlett, M., Rayner, J., and Wilson, J. (2001). In Search of Sustainability: British Columbia's Forest Policy in the 1990s. University of British Columbia Press, Vancouver.

Cathro, J. (2004). Generating revenue: marketing your logs. In Gunter, J. (ed.), The Community Forestry Guidebook: Tools and Techniques for Communities in British Columbia, FORREX and BCCFA, pp 61-66, FORREX Series 15.

Dobbin, M. (2006). Commentary: Emerson not at B.C.'s Service. The Georgia Strait. March 2. http://www.straight.com/content.cfm? $\mathrm{id}=16342$.

Donovan, P. (1999). Creating an Open Log Market in Interior British Columbia. Managing Wholes: Creating a Future that Works. http://managingwholes.com/index.php.

Elias, H. (2000). Harrop and Procter. How a Persistent Community Fashioned its Own Forestry Future. Ecoforestry 15: 218-26.

Feit, H. (2004). Contested identities of "Indians" and "Whitemen" at James Bay, or the power of reason, hybridity and agency. In Irimoto, T., and Yamada, T. (eds.), Circumpolar Ethnicity and Identity. Senri Ethnological Studies, Osaka, pp. 109-126.

Forest Practices Code of British Columbia Act. (1994). B.C. Forestry Law. www.canadalawbook.ca.

Gunter, J. (ed.) (2004). The Community Forestry Guidebook: Tools and Techniques for Communities in British Columbia, FORREX and BCCFA. FORREX Series 15.

Hamilton, G. (2006). Forestry Changes Failing Truck Loggers: Market Forces Derailed Changes, they Say. The Vancouver Sun. November 23rd.

Hayter, R. (2003). "The War in the Woods": Post-fordist Restructuring, Globalization, and the Contested Remapping of British Columbia's Forest Economy. Annals of the Association of American Geographers 93: 3706-729.

Hoberg, G. (2001). The 6\% solution: the forest practices code. In Cashore, B., Hoberg, G., Howlet, M., Rayner, J., and Wilson, J. (eds.), In Search of Sustainability: British Columbia Forest Policy in the 1990s. University of British Columbia Press, Vancouver.

Klenner, W., and Huggard, D. (1995). Procedures for Ranking Landscape Units for Biodiversity Emphasis Allocation in the Kamloops LRMP, Ministry of Forests, Kamloops Region, 18 pp.

Krogman, N., and Beckley, T. (2002). Corporate "Bail-Out" and local "Buyouts": Pathways to Community Forestry. Society \& Natural Resources 15: 2109-127.

Langdon, S. (2006). "Ish": Exploring a Tlingit Relational Concept and Associated Practices with SAlmon. Paper presented at the ISSRM conference, Vancouver.

Lemos, M., and Agrawal, A. (2006). Environmental Governance. Annual Review of Environment and Resources 31: 297-325.

Lerner, S. (ed.) (1993). Environmental Stewardship: Studies in Active Earthkeeping, University of Waterloo, Dept. of Geography, Waterloo, ONT.
Lockie, S., and Higgins, V. (2007). Roll-out Neoliberalism and Hybrid Practices of Regulation in Australian Agri-environmental Governance. Journal of Rural Studies 23: 1-11.

Maness, T., and Nelson, H. (2007) The Separation of Land Management and Manufacturing in Forest Tenures in BC. Working Paper for the BC Forum on Forest Economics and Policy.

Marchak, P., and Allen, S. D. (2003). BC Forests 2003. An Appraisal of Government Policies. Report to the David Suzuki Foundation. Vancouver BC.

Mater, C., and Mater, S. (1998). Vernon Forestry: Log Sorting for Profit. In Jenkins, M., and Smith, E. (eds.), The Business of Sustainable Forestry. Strategies for an Industry in Transition. Island Press, Washington, DC, pp. 148-156.

McCarthy, J. (2006). Neoliberalism and the Politics of Alternatives: Community Forests in British Columbia and the United States. Annals of the Association of American Geographers 96: 184104.

M'Gonigle, M. (1998a). Living communities in a living forest: towards an ecosystem-based structure of local tenure and management. In Tollefson, C. (ed.), The Wealth of Forests: Markets, Regulation, and Sustainable Forestry. University of British Columbia Press, Vancouver, pp. 102-119.

M'Gonigle, M. (1998b). Structural instruments and sustainable forests: a political ecology approach. In Tollefson, C. (ed.), The Wealth of Forests: Markets, Regulation, and Sustainable Forestry. University of British Columbia Press, Vancouver, pp. $152-185$.

Niquidet, K., and van Kooten, G. C. (2006). Transaction Evidence Appraisal: Competition in British Columbia's Stumpage Markets. Forest Science 52: 4451-459.

Pearse, P. H. (2001). Crisis and Opportunity in the Coast Forest Industry. A Report to the Minister of Forests on British Columbia's coastal forest industry. http://www.for.gov.bc.ca/hfd/ library/documents/phpreport/.

Peck, J., and Tickell, A. (2002). Neoliberalizing Space. Antipode 34: $3380-404$

Peel, A. L. (1991). The Forest Resources Commission: The Future of our Forests. Ministry of Forests and Range, Victoria, BC.

Peluso, N. (1995). Whose Woods are These? Counter-mapping Forest Territories in Kalimantan, Indonesia. Antipode 27: 4383-406.

Pinkerton, E. W. (1987). Competition among B.C. fish processing firms. In Marchak, P., Guppy, N., and McMullan, J. (eds.), Uncommon Property: The Fishing and Fish Processing Industries of British Columbia. University of British Columbia Press, Vancouver, pp. 66-91.

Pinkerton, E. W. (1993). Analyzing Co-management Efforts as Social Movements: The Tin-Wis Coalition and the Drive for Forest Practice Legislation in British Columbia. Alternatives 19: 333-38.

Pinkerton, E. (2003). Toward specificity in complexity: understanding co-management from a social science perspective. In Douglas, W. C., Nielsen, J. R., and Degnbol, P. (eds.), The Fisheries Comanagement Experience: Accomplishments, Challenges And Prospects. Kluwer, Dordrecht, pp. 61-77.

Pinkerton, E., and Weinstein, M. (1995). Fisheries that Work. Sustainability Through Community-based Management, David Suzuki Foundation, \#219, 2211 West 4th Ave., Vancouver, BC. V6K 4S2, $199 \mathrm{p}$

Pinnell, H., and Elias, H. (2002). How the Harrop-Procter Community is Harvesting its Forest. Ecoforestry 17: 48-16.

Province of British Columbia. (1993). A Protected Areas Strategy for British Columbia. The Protected Areas Component of B.C. 's Land Use Strategy, Land Use Coordination Office, Victoria, 39 pp. 
Prudham, S. (2007). Sustaining Sustained Yield: Class, Politics, and Post-war Forest Regulation in British Columbia. Environment and Planning D: Society and Space 25: 258-283.

Schlager, E., and Ostrom, E. (1993). Property rights regimes and coastal fisheries: an empirical analysis. In Anderson, T. L., and Simmons, R. T. (eds.), The Political Economy of Customs and Culture: Informal Solutions to the Commons Problem. Rowman and Littlefield, Lanham, MD, pp. 13-41.

Scott, J. C. (1985). Weapons of the Weak: Everyday Forms of Peasant Resistance. Yale University Press, New Haven.

Scott, J. C. (1998). Seeing Like a State. Yale University Press, New Haven.

Sheppard, S. (2003). Knowing a Socially Sustainable Forest when you See One: Implications for Results-based Forestry. The Forestry Chronicle 79: 5865-875.

Silva Forest Foundation. (2004). The Power of Community: Applying Ecosystem-based Conservation Planning Across Canada. Slocan Park, BC.

Silver, J. J., Heaslip, R., Pinkerton, E., Furman, K., Nephin, J., and Williamson, I. (2007). Co-Management as Adaptive Resistance to the Neo-liberal Governance Paradigm: Theoretical Considerations. Paper read to the Meeting of The Association of American Geographers, San Francisco.
Slocan Valley Community Forest Management Project. (1975). Final Report. Box 81, Winlaw, BC.

Smith, J. (1997). Bringing Ecoforestry to the BC Forest Service. Global Biodiversity Magazine, Canadian Museum of Nature. http://www.nature.ca/english/gbzine.htm.

St. Martin, K. (2001). Making Space for Community Resource Management in Fisheries. Annals of the Association of American Geographers 91: 1122-142.

Swyngedouw, E. (2005). Governance Innovation and the Citizen: The Janus Face of Governance-beyond-the-state. Urban Studies 42: 11991-2006.

Tobias, T. (2000). Chief Kerry's Moose: A Guidebook to Land Use and Occupancy Mapping, Research Design and Data Collection. Union of BC Indian Chiefs and Ecotrust Canada, Vancouver, BC.

Wilson, J. (2001). Experimentation on a Leash: Forest Land Use Planning in the 1990s. In Cashore, B., Hoberg, G., Howlet, M., Rayner, J., and Wilson, J. (eds.), In Search of Sustainability: British Columbia Forest Policy in the 1990s. University of British Columbia Press, Vancouver, pp. 31-60.

Young, N., and Matthews, R. (2007). Resource Economies and Neoliberal Experimentation: The Reform of Industry and Community in Rural British Columbia. Area 39: 2176-185. 